\title{
MUTGEN01464
}

\section{Sister-chromatid exchange and chromosome aberrations for 4 aliphatic epoxides in mice}

\author{
A.K. Giri, E.A. Messerly and J.E. Sinsheimer \\ College of Pharmacy, University of Michigan, Ann Arbor, MI 48109-1065 (U.S.A.) \\ (Received 19 December 1988) \\ (Revision received 13 March 1989) \\ (Accepted 20 March 1989)
}

Keywords: Aliphatic epoxides; In vitro vs. in vivo tests; Sister-chromatid exchange; Chromosome aberrations

\section{Summary}

Sister-chromatid exchange (SCE) and chromosome aberrations (CA) in bone marrow cells were analyzed after in vivo exposure in mice to 4 aliphatic epoxides, namely 1-naphthyl glycidyl ether (NGE), 1-naphthyl propylene oxide (NPO), 4-nitrophenyl glycidyl ether (NPGE) and trichloropropylene oxide (TCPO). These compounds were selected as being among the most mutagenic aliphatic epoxides in our previous structure-mutagenicity studies with the Ames test. There were significant dose-related increases in SCE and CA results for all 4 epoxides. The order of genotoxicity as established through SCE was NGE $>$ NPO $>\mathrm{NPGE} \cong \mathrm{TCPO}>$ solvent control. It is of interest that Ames Salmonella results are consistent with in vivo genotoxicity for these compounds. However, only the plate test version of the Ames procedure is consistent with this order of in vivo genotoxicity and neither preincubation Ames testing results nor chemical alkylation rates would have predicted this order.

Aliphatic epoxides are widely used industrial intermediates as well as laboratory reagents and can be produced as metabolic intermediates. Because of the established role of epoxides as arene oxides in the carcinogenicity of polycyclic aromatic hydrocarbons, questions have been raised concerning the genotoxicity of epoxides in general (Manson, 1980; Ehrenberg and Hussain, 1981). We have been interested in structure-mutagenicity relationships for aliphatic epoxides (Wade et al., 1978; Frantz and Sinsheimer, 1981; Neau et al., 1982; Frantz et al., 1985; Djuric et al., 1986;

Correspondence: Dr. J.E. Sinsheimer, College of Pharmacy, University of Michigan, Ann Arbor, MI 48109-1065 (U.S.A.).
Rosman et al., 1986, 1987, 1988). In agreement with Manson (1980), Ehrenberg and Hussain (1981) and Hopkins (1984) we recognize the need to extend the base of in vitro studies to in vivo genotoxicity testing. We have selected sister-chromatid exchange (SCE) and chromosome aberrations (CA) testing as a logical starting point for an in vivo short-term evaluation of the genotoxicity of aliphatic epoxides. To date there have only been limited reports of SCE, CA and related in vivo testing of such compounds. Various investigators (Yager et al., 1983; Hogstedt et al., 1983; Sarto et al., 1983; Stolley et al., 1984; Galloway et al., 1986) have established statistically significant increases in SCE and/or CA rates for peripheral blood lymphocytes of workers exposed to ethylene 
oxide as compared to the lymphocytes from control groups. Hogstedt et al. (1983) also found increased levels of micronuclei in the bone marrow cells of exposed workers. Under laboratorycontrolled conditions, Kligerman et al. (1983) were able to establish a concentration-dependent increase in SCE for the lymphocytes of rats exposed to ethylene oxide. The genotoxicity of propylene oxide has been examined in mice where an increase in the number of micronucleated erythrocytes was observed following i.p. administration (Bootman et al., 1979). Styrene oxide has also been studied in mice (Fabry et al., 1978; Loprieno et al., 1978) and Chinese hamsters (Norppa et al., 1979) with only the study by Loprieno et al. establishing positive in vivo genotoxicity. Recently, Sharief et al. (1986) found butadiene monoxide to be an effective inducer of SCE and CA in bone marrow cells of mice following i.p. injection. Walk et al. (1987) found diepoxybutane to increase CA and SCE rates in both mice and Chinese hamsters following either i.p. injection or exposure by inhalation.

It is the purpose of this paper to study SCE and $\mathrm{CA}$ in vivo genotoxic effects in bone marrow cells of mice for 4 of the most mutagenic aliphatic epoxides we have tested to date with Salmonella and to compare the in vivo and in vitro results. The compounds to be studied are 1-naphthyl glycidyl ether (Rosman et al., 1988), 1-naphthyl propylene oxide (Rosman et al., 1987), 4nitrophenyl glycidyl ether (Neau et al., 1982) and 3,3,3-trichloropropylene oxide (Djuric et al., 1986).

\section{Materials and methods}

\section{Animals}

Male CD1 mice 10-12 weeks old, weighing 30 $\mathrm{g}$, were purchased from Charles River Breeding Laboratories (Wilmington, MA). They were kept 5 per cage with wood chip bedding, were fed chow (Purina) and water ad libitum and were housed 4-5 days prior to the start of the experiment.

\section{Chemicals}

5-Bromodeoxyuridine (BrdU) tablets $(50 \mathrm{mg}$ each) were purchased from Boehringer Mannheim Biochemicals (Indianapolis, IN). Colchicine and 7,12-dimethylbenz $[a]$ anthracene (DMBA) were purchased from Sigma Chemical Co. (St. Louis, MO) while dimethyl sulfoxide (DMSO), 3,3,3-trichloropropylene oxide (TCPO) and 4-(4-nitrobenzyl)pyridine were obtained from Aldrich Chemical Co. (Milwaukee, WI). 4-Nitrophenyl glycidyl ether (NPGE) was obtained from Eastman (Rochester, NY) and purified by repeated recrystallization from ethanol. 1-Naphthyl glycidyl ether (NGE) and 1-naphthyl propylene oxide (NPO) were prepared in this laboratory as previously described (Rosman et al., 1987, 1988).

\section{In vivo sister-chromatid exchange assay}

Paraffin-coated BrdU tablets $(50 \mathrm{mg}$ ) following the methodology of McFee et al. (1983) and Sharief et al. (1986) were used for in vivo SCE studies and cell replication kinetics analyses. Approximately $80 \%$ of the surface of the tablets was coated with embedding paraffin and implanted subcutaneously on the flank of mice under ether anesthesia. The test chemical was administered as a single i.p. injection $30 \mathrm{~min}$ after tablet implantation. 5 doses per test chemical (Table 1) in $75 \mu$ l of DMSO were used as determined from preliminary range-finding experiments. The maximal dose used in our comparison of genotoxicity was $200 \mathrm{mg} / \mathrm{kg}$ which was set by the acute toxicity of the least genotoxic compound, TCPO. 5 animals were used for each concentration. Negative control mice were injected with $75 \mu$ l of DMSO while DMBA was used as a positive control at a dose of $50 \mathrm{mg} / \mathrm{kg}$ body weight. For SCE analyses, colchicine (4 $\mathrm{mg} / \mathrm{kg}$ ) was injected (i.p.) $22 \mathrm{~h}$ after the $\mathrm{BrdU}$ tablet implantation. $2 \mathrm{~h}$ later, bone marrow was expelled with $0.075 \mathrm{M} \mathrm{KCl}$. After hypotonic treatment $(0.075 \mathrm{M} \mathrm{KCl})$ for $20 \mathrm{~min}$, cells were fixed 3 times with methanol-acetic acid $(3: 1)$. The slides were prepared and chromosomes were differentially stained (fluorescence-plus-Giemsa technique) in accordance with standard cytogenetic methods (Perry and Wolff, 1974; Latt et al., 1981; Giri et al., 1986, 1987). All the slides were coded and observed by a single observer. 30 , second division cells, $(40 \pm 2$ chromosomes $)$-per animal were scored for SCE frequencies, i.e. a total of 150 cells were scored per concentration tested. Randomly selected metaphase cells (200/animal) were scored for cell replication kinetic analyses by their staining patterns as first $\left(\mathbf{M}_{1}\right)$, second $\left(\mathbf{M}_{2}\right)$ and 
third $\left(\mathrm{M}_{3}\right)$ division metaphases. The replicative indices (RI) were calculated as follows: $\mathrm{RI}=\left(1 M_{1}\right.$ $\left.+2 M_{2}+3 M_{3}\right) / 200$ (Krishna et al., 1985).

\section{Chromosome aberration assay}

For CA analyses 4 concentrations (Table 2) of the above 4 chemicals were injected (i.p.) following the protocol of Preston et al. (1987). As preliminary studies with TCPO, the compound with the shortest half-life, indicated no difference for the shorter fixation times suggested in that protocol, the 24-h time was used for our comparison to the SCE results. After $22 \mathrm{~h}$ the animals were injected (i.p.) with colchicine $(2 \mathrm{mg} / \mathrm{kg})$. Then, after $2 \mathrm{~h}$ animals were sacrificed by cervical dislocation and bone marrow chromosomes were prepared as described above and slides were stained with Giemsa (1:20 dilution). Negative control mice were injected with DMSO (75 $\mu \mathrm{l} /$ mouse), while positive control animals received $100 \mathrm{mg} / \mathrm{kg}$ of DMBA in $75 \mu 1$ DMSO. All the slides were coded and observed by a single observer. 100 well-spread metaphase cells were scored per animal from each of 5 animals at each concentration tested. Mitotic indices (MI) were calculated from 1000 cells/animal and expressed as percentages. CA were scored following the method of WHO (1985) and Preston et al. (1987). The aberration frequencies per cell for chromatid and chromosome types were calculated. Gaps were recorded (Table 2) but not included in the frequency of aberrations per cell.

\section{Mutagenicity test}

Single-dose comparisons for all 4 epoxides were made at $0.25 \mu$ mole/plate with Salmonella strain TA100 without S9 activation (where $n=6$ ). These comparisons for either the plate incorporation or preincubation method of Maron and Ames (1983) were made on the same day using bacteria from the same overnight culture.

\section{Statistical analysis}

Dunnett's control group comparison test (1sided) was used for all chemicals, except TCPO, to compare SCE, CA and MI results with those for the negative control animals, while the 2 -sided test was used for the RI comparisons. Because of unequal sample sizes due to animal death in the TCPO series, Tukey's test was used to make these comparisons of test results with their respective negative controls (Dunnett, 1980). The trend test method of Margolin et al. (1986), based upon the square root of the dose as the independent variable, was applied to the SCE and CA data with modification of Eqn. 7 to facilitate the computation of standard errors and comparisons between chemicals.

\section{Results and discussions}

SCE frequencies and RI for mice exposed to 4 aliphatic epoxides are shown in Table 1. The non-polar nature of our compounds required the use of DMSO as the solvent for their i.p. administration and as suggested by Preston et al. (1987), DMBA was used as a non-polar positive control. A significant increase in the SCE frequency $(p<$ 0.05 ) was observed for NPO at all the concentrations tested when compared with the solvent control. NGE and NPGE showed significant increases in SCE except for the lowest concentration when compared with control. With TCPO, the only significant increase in SCE was observed in the $100-\mathrm{mg} / \mathrm{kg}$-treated group. No significant differences were observed in cell replication kinetics with any of the epoxides tested when compared with the control. In the case of TCPO, the 200 $\mathrm{mg} / \mathrm{kg}$ dose killed 2 of the 5 animals in this exposure group. The positive control chemical (DMBA) gave a high frequency of SCE $(14.25 /$ cell $)$ which is in agreement with that reported in mice by Tice et al. (1987), but where DMBA was injected $1 \mathrm{~h}$ after BrdU tablet implantation. Table 2 shows the CA and mitotic indices in mice exposed to the 4 epoxides. Aberrations per cell for chromatid and chromosome types are presented (Preston et al., 1987) and percentages of aberrant cells are used for statistical calculations (Sharief et al., 1986). NGE and NPO showed a significant increase in the percentage of $\mathrm{CA}$ at all 4 concentrations tested compared to the negative control. NPGE also showed significant increases at the higher 3 concentrations and TCPO showed significant increases of CA only at the higher 2 concentrations. There was a decrease in MI at the higher doses for the 4 epoxides indicating toxicity to bone marrow cells at these higher concentrations. In confirmation of the SCE study, TCPO 
TABLE 1

SISTER-CHROMATID EXCHANGE INDUCED BY 4 ALIPHATIC EPOXIDES IN VIVO IN MICE

\begin{tabular}{|c|c|c|c|}
\hline Treatment & $\mathrm{SCE} /$ cell of 5 animals & $\begin{array}{l}\mathrm{SCE} / \text { cell } \\
(\text { mean } \pm \text { S.D.) }\end{array}$ & $\begin{array}{l}\text { Replicative indices } \\
\text { (mean } \pm \text { S.D.) }\end{array}$ \\
\hline \multicolumn{4}{|l|}{ Solvent control } \\
\hline DMSO $(75 \mu \mathrm{l})$ & $3.6,3.8,3.1,3.4,4.1$ & $3.60 \pm 0.38$ & $1.81 \pm 0.09$ \\
\hline \multicolumn{4}{|l|}{ NGE (mg/kg) } \\
\hline 5 & $4.7,4.9,4.6,4.9,4.2$ & $4.68 \pm 0.29$ & $1.75 \pm 0.19$ \\
\hline 10 & $6.6,6.9,5.1,5.8,5.3$ & $5.98 \pm 0.79 * *$ & $1.79 \pm 0.06$ \\
\hline 50 & $8.5,8.4,6.8,7.0,7.3$ & $7.58 \pm 0.79 * *$ & $1.75 \pm 0.08$ \\
\hline 100 & $10.1,12.4,11.9,9.4,8.3$ & $10.43 \pm 1.73 * *$ & $1.71 \pm 0.10$ \\
\hline \multicolumn{4}{|l|}{$\mathrm{NPO}(\mathrm{mg} / \mathrm{kg})$} \\
\hline 5 & $4.3,5.1,4.6,4.3,4.0$ & $4.45 \pm 0.41 *$ & $1.82 \pm 0.09$ \\
\hline 10 & $5.2,5.4,4.7,5.8,5.4$ & $5.32 \pm 0.39 * *$ & $1.84 \pm 0.08$ \\
\hline 10 & $4.1,4.0,4.9,3.9,3.7$ & $4.13 \pm 0.45$ & $1.87 \pm 0.10$ \\
\hline 25 & $6.6,5.4,4.3,4.2,4.2$ & $4.93 \pm 1.06^{*}$ & $1.83 \pm 0.11$ \\
\hline 50 & $5.3,6.6,5.3,4.6,5.0$ & $5.37 \pm 0.77 * *$ & $1.82 \pm 0.11$ \\
\hline 100 & $5.1,5.5,4.9,5.5,6.3$ & $5.46 \pm 0.54 * *$ & $1.88 \pm 0.09$ \\
\hline 200 & $4.8,5.7,4.2,4.9,6.0$ & $5.13 \pm 0.72 * *$ & $1.82 \pm 0.07$ \\
\hline \multicolumn{4}{|l|}{ TCPO (mg/kg) } \\
\hline 10 & $3.8,3.9,4.5,3.8,3.3$ & $3.85 \pm 0.43$ & $1.81 \pm 0.11$ \\
\hline 25 & $5.1,4.2,4.5,3.7,4.2$ & $4.35 \pm 0.52$ & $1.85 \pm 0.05$ \\
\hline 50 & $4.3,5.1,4.0,4.1,4.5$ & $4.40 \pm 0.44$ & $1.82 \pm 0.07$ \\
\hline 100 & $5.7,4.8,5.6,4.6,4.4$ & $5.02 \pm 0.60 * *$ & $1.82 \pm 0.13$ \\
\hline \multicolumn{4}{|l|}{ Positive control } \\
\hline
\end{tabular}

a Mean \pm S.D. for 5 animals (30 cells/animal). Results at each concentration were compared to those of the control using Dunnett's test, except for TCPO where Tukey's test was used ( ${ }^{*} p<0.05$ and ${ }^{*} p<0.01$ ).

b 2 of the 5 animals died at this concentration.

was toxic at $200 \mathrm{mg} / \mathrm{kg}$ killing 3 of the 5 animals. The positive control chemical (DMBA) gave a higher percentage of CA (12.80\%) than those of the solvent control and treated groups.

As summarized in Table 3, statistically significant dose-response trend tests could be estimated for both SCE and CA results for all 4 epoxides. Thus, the genotoxicity of these compounds was clearly established in mice. Differences in these trend tests were used in an attempt to compare the genotoxic potency of the epoxides. For the SCE results, there were statistically significant differences between chemicals except between NPGE and TCPO. Therefore, the order of genotoxicity in SCE level based upon these trends could be listed as NGE $>\mathrm{NPO}>\mathrm{NPGE} \cong \mathrm{TCPO}$. While the CA results were in general agreement with $\mathrm{SCE}$, the decreased sensitivity of the CA data did not allow ranking of these results. That is, the $\mathrm{CA}$ results for NGE were significantly greater than those for NPGE and TCPO. In addition, NPO was also greater than NPGE, but significant differences were not established between the other pairs of compounds (Table 3).

Among the in vivo studies of the genotoxicity of aliphatic epoxides listed in our introduction, 
TABLE 2

CHROMOSOMAL ABERRATIONS INDUCED BY 4 ALIPHATIC EPOXIDES IN BONE MARROW CELLS OF MICE

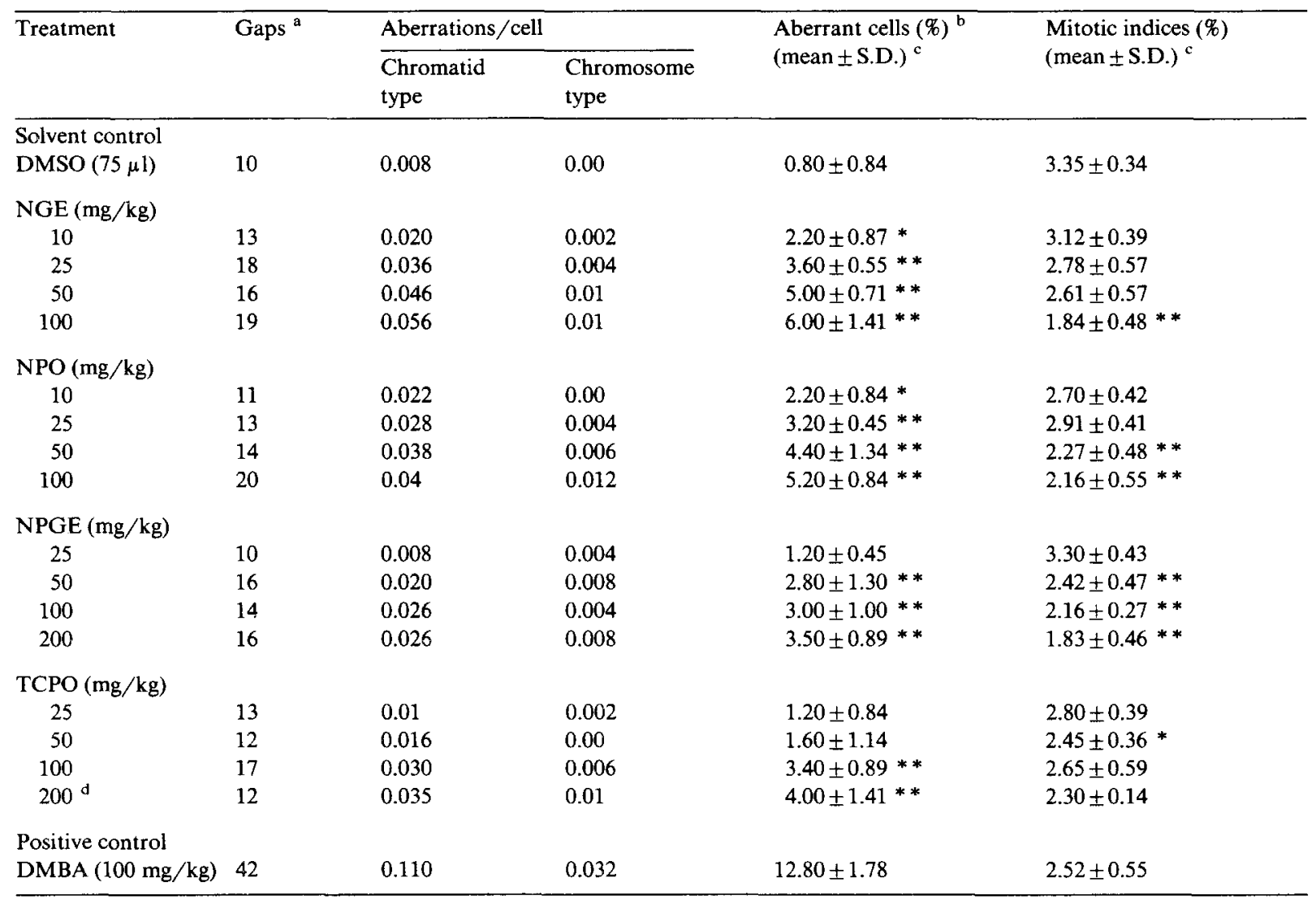

a Total chromatid and chromosome gaps at each concentration were recorded but not included as aberrations.

b Cells with at least 1 aberration. Results are for 5 animals at each concentration (100 cells/animal) except where noted.

c Results at each concentration were compared to those of the control using Dunnett's test, except for TCPO where Tukey's test was used $\left(^{*} p<0.05\right.$ and $\left.* * p<0.01\right)$.

d 3 of the 5 animals died at this concentration.

only a few included bone marrow studies and thus permit direct comparison to this present investigation. Hogstedt et al. (1983) noted a statistically significant increase in the levels of micronuclei in erythroblasts and polychromatic erythrocytes in their study of the bone marrow cells of workers exposed to ethylene oxide as compared to a control group. Bootman et al. (1979), after oral administration of propylene oxide in doses up to $2 \times 500 \mathrm{mg} / \mathrm{kg}$ in mice, could not detect an increase in micronucleated polychromatic erythrocytes but did detect a significant increase following 2 i.p. injections at $300 \mathrm{mg} / \mathrm{kg}$. In one study with styrene oxide, Fabry et al. (1978) could not induce an increase in micronuclei in the polychromatic erythrocytes in the bone marrow of mice following an i.p. injection of $250 \mathrm{mg} / \mathrm{kg}$. In another study, Norppa et al. (1979) reported negative results for their SCE and CA tests following inhalation exposure of Chinese hamsters at levels up to $100 \mathrm{ppm}$ for 4 days as well as at $25 \mathrm{ppm}$ for 20 days. They also reported negative $\mathrm{CA}$ results at an i.p. dose of $500 \mathrm{mg} / \mathrm{kg}$ and positive SCE results in the cultured bone marrow cells from only 1 animal in 6 at this lethal dose. However, Loprieno et al. (1978) did establish a dose-response relationship for $\mathrm{CA}$ results in mice following oral administration of styrene oxide. Their CA 
TABLE 3

TREND TESTS FOR SCE AND CA EXPERIMENTS AND COMPARISON BETWEEN CHEMICALS

\begin{tabular}{|c|c|c|}
\hline Test & $\begin{array}{l}\mathrm{SCE}^{\mathrm{a}} \\
\text { (trend } \pm \text { S.E.) }\end{array}$ & $\begin{array}{l}\mathrm{CA}^{\mathrm{b}} \\
\text { (trend } \pm \text { S.E.) }\end{array}$ \\
\hline NGE & $0.65465 \pm 0.02507^{* *}$ & $0.00049 \pm 0.00011 * *$ \\
\hline NPO & $0.45160 \pm 0.01984 * *$ & $0.00040 \pm 0.00011^{* *}$ \\
\hline NPGE & $0.11438 \pm 0.01102 * *$ & $0.00012 \pm 0.00004^{*}$ \\
\hline TCPO & $0.10251 \pm 0.01192 * *$ & $0.00018 \pm 0.00006 * *$ \\
\hline \multicolumn{3}{|c|}{ Differences in trend tests } \\
\hline NGE - NPO & $0.20305 \pm 0.02949 * *$ & $0.00008 \pm 0.00015$ \\
\hline NGE-NPGE & $0.54027 \pm 0.02528 * *$ & $0.00036 \pm 0.00012 * *$ \\
\hline $\mathrm{NGE}-\mathrm{TCPO}$ & $0.55214 \pm 0.02538 * *$ & $0.00030 \pm 0.00013 *$ \\
\hline NPO - NPGE & $0.33722 \pm 0.02011 * *$ & $0.00028 \pm 0.00011 *$ \\
\hline NPO-TCPO & $0.34909 \pm 0.02024 * *$ & $0.00022 \pm 0.00012$ \\
\hline NPGE-TCPO & $0.01187 \pm 0.01311$ & $-0.00006 \pm 0.00007$ \\
\hline
\end{tabular}

a Number of counts vs. square root of dose.

b Percentage vs. square root of dose.

* Significant at $p<0.05$.

** Significant at $p<0.01$.

values in terms of chromatid and chromosome types per cell were, at their highest oral doses (500 and $1000 \mathrm{mg} / \mathrm{kg}$ ), less than our lowest doses i.p. for all the compounds in the present study.

Recently Walk et al. (1987) have reported increases in CA and SCE rates in bone marrow cells for both inhalation and i.p. administration of diepoxybutane to Chinese hamsters and mice. They established, as was also true for the interlaboratory results for styrene oxide, that the bone marrow cells of mice were more sensitive than those of Chinese hamsters for their aliphatic epoxide. The $\mathrm{CA}$ and SCE results reported by these investigators for diepoxybutane, with similar experimental conditions to those used in the present investigation, are much higher than the results for our epoxides. At least in part, this may be explained by the presence of 2 epoxide groups. The SCE and $\mathrm{CA}$ effects in the bone marrow of mice following i.p. injection of butadiene monoxide were also studied with conditions similar to ours (Sharief et al., 1986). While their CA responses for $18 \mathrm{~h}$ following treatment were similar to our results for NPO and NGE up to $50 \mathrm{mg} / \mathrm{kg}$ for $24 \mathrm{~h}$, their results at $100 \mathrm{mg} / \mathrm{kg}$ were much higher for butadiene monoxide as were the SCE results at all levels. The presence of the double bond in conjugation with the epoxide, especially with its poten- tial for metabolic activation to a second epoxide, would appear to be a factor in the genotoxicity of butadiene monoxide.

Previously we have established the dose-mutagenicity relationships for NGE, NPO, NPGE, TCPO and related compounds in Salmonella using the Ames procedure (Neau et al., 1982; Djuric et al., 1986; Rosman et al., 1987, 1988). Based upon these dose-response relationships a concentration of $0.25 \mu \mathrm{mole} / \mathrm{plate}$, which provided maximal variation among the 4 compounds of interest without toxicity to the bacteria, was selected for direct comparison of mutagenicity with Salmonella strain TA100. Concurrent comparisons were made with the same overnight culture to reduce day-today intralaboratory variations (Cheli et al., 1980) and to control fluctuations due to differences in bacterial growth rate (Salmeen and Durisin, 1981). The results for this concurrent testing with both the plate incorporation and preincubation assays of Maron and Ames (1983) are given in Table 4. Also included in this table is a comparison of the rates of alkylation of 4-(4-nitrobenzyl)pyridine at $37^{\circ} \mathrm{C}$ for $20 \mathrm{~min}$ by the previously described method (Hemminki and Falck, 1979; Nelis et al., 1982).

Mutagenicity does not correlate with reactivity for the compounds listed in Table 4. The lack of such correlation was expected from our previous mutagenicity studies where the extent of aromatic

\section{TABLE 4}

MUTAGENICITY ASSAYS WITH SALMONELLA STRAIN TA100 AT $0.25 \mu$ mole/TEST AND CHEMICAL REACTIVITY DATA

\begin{tabular}{|c|c|c|c|}
\hline \multirow[t]{2}{*}{ Compounds } & \multicolumn{2}{|l|}{ Revertants } & \multirow[t]{2}{*}{ Reactivity " } \\
\hline & Plate test ${ }^{\mathbf{a}}$ & $\begin{array}{l}\text { Preincubation } \\
\text { test }^{h}\end{array}$ & \\
\hline Control (DMSO) & $79 \pm 10$ & $141 \pm 15$ & \\
\hline NGE & $2102 \pm 239$ & $1613 \pm 239$ & $0.288 \pm 0.012$ \\
\hline NPO & $2096 \pm 114$ & $1437 \pm 95$ & $0.098 \pm 0.003$ \\
\hline NPGE & $929 \pm 104$ & $987 \pm 227$ & $0.214 \pm 0.005$ \\
\hline ТСPO & $137 \pm 16$ & $1274 \pm 116$ & $2.611 \pm 0.078$ \\
\hline
\end{tabular}

a Mean revertants/plate \pm S.D., where $n=6$.

${ }^{b}$ Mean revertants/plate \pm S.D. from each of 2 preincubation tubes, where $n=3$ for each tube.

c Absorbance after reaction with 4-(4-nitrobenzyl)pyridine at $37^{\circ} \mathrm{C}$ for $20 \mathrm{~min}$, where $n=6$. 
unsaturation and/or resulting more planar structure of the naphthyl derivatives was a more important parameter for relative mutagenicity than chemical reactivity (Rosman et al., 1987, 1988). Nor do our measures of genotoxicity in the bone marrow of mice correlate to chemical reactivity, with TCPO, the least genotoxic epoxide, being the most chemically reactive. This is in spite of the fact that, with the exception of reactivity with thymidine, there was in general good correlation of adduct formation in vitro with nucleosides for a series of epoxides which included TCPO (Djuric et al., 1986). An important consideration in the lack of correlation of our in vivo genotoxicity in bone marrow cells to in vitro measures of the reactivity of the epoxides would be their biological half-lives. Norppa et al. (1981) have found that the high alkylation rate of TCPO in comparison to their other epoxides contrasts with the low capacity of TCPO to induce CA and SCE results in cultured human lymphocytes. They propose a greater rate of detoxication and present evidence for a shorter half-life for TCPO to explain this difference. Indeed, in our study of the detoxication of aliphatic epoxides, which included TCPO and NPGE, the rate of detoxication did depend upon chemical reactivity (Sinsheimer et al., 1987). Therefore in the present study, it is postulated that TCPO with its much greater chemical reactivity has the shortest half-life and therefore its concentration in the bone marrow over the period of time necessary to produce $\mathrm{CA}$ and SCE results is reduced to the greatest extent.

The contrast in relative mutagenicity for TCPO in Table 4 between the preincubation and plate versions of the Ames test has been observed before for other epoxide studies (Norppa et al., 1981; Djuric et al., 1986). This might again be explained on the basis of the reactivity of TCPO leading to its deactivation. In the preincubation test, the epoxides interact directly with bacteria at an optimal portion of their growth phase and thus react with the buffer for a minimal period of time. However, with the plate test, the work of Barber et al. (1983) suggests that the mutagen must be present 4-16 $\mathrm{h}$ after plating. Therefore, TCPO would have more time for inactivation and with a more complex medium than in the preincubation procedure. The end result for this series of epoxides is that the order of mutagenicity in the plate version of the Ames procedure is a better predictor for our in vivo bone marrow results than would be the preincubation results.

It is of interest, however, in the present study that even with its greater rate of detoxication, TCPO produces CA and SCE results at the higher doses which are significantly greater than their negative controls. Also, in agreement with our in vitro results, naphthyl groups on the aliphatic epoxides enhanced in vivo genotoxicity. This study in establishing positive $\mathrm{CA}$ and SCE results in mice for NGE, NPO, NPGE and TCPO adds to the previously limited evidence for the in vivo genotoxicity of aliphatic epoxides.

\section{Acknowledgements}

The authors express their appreciation to Dr. Bruce Ames, University of California at Berkeley for supplying Salmonella strain TA100 and to the Statistical Research Laboratory, University of Michigan for their assistance in the analysis of our data.

The investigation was supported by Grant RO1 ES03345 from the National Institute of Environmental Health Sciences, DHHS.

\section{References}

Barber, E.D., W.H. Donish and K.R. Mueller (1983) The relationship between growth and reversion in the Ames Salmonella plate incorporation assay, Mutation Res., 113, 89-101.

Bootman, J., D.C. Lodge and H.E. Whalley (1979) Mutagenic activity of propylene oxide in bacterial and mammalian systems, Mutation Res., 67, 101-112.

Cheli, C., D. Francesco, L.A. Petrullo, E.C. McCoy and H.S. Rosenkranz (1980) The Salmonella mutagenicity assay: reproducibility, Mutation Res., 74, 145-150.

Djuric, Z., B.H. Hooberman, L.B. Rosman and J.E. Sinsheimer (1986) Reactivity of mutagenic propylene oxides with deoxynucleosides and DNA, Environ. Mutagen., 8, 369-383.

Dunnett, C.W. (1980) Pair-wise multiple comparison in the homogeneous variance, unequal sample size case, J. Am. Stat. Assoc., 75, 789-795.

Ehrenberg, L., and S. Hussain (1981) Genetic toxicity of some important epoxides, Mutation Res., 86, 1-113.

Fabry, L., A. Leonard and M. Roberfroid (1978) Mutagenicity tests with styrene oxide in mammals, Mutation Res., 51, $377-381$. 
Frantz, S.W., and J.E. Sinsheimer (1981) Bacterial mutagenicity and toxicity of cycloaliphatic epoxides, Mutation Res., $90,67-78$.

Frantz, S.W., E. Van den Eeckhout, J.E. Sinsheimer, M. Yashihara and $M$. Koreeda (1985) Mutagenicity in Salmonella assay of cyclohexane epoxide derivatives, Toxicol. Lett., 25, 265-271.

Galloway, S.M., P.K. Berry, W.W. Nichols, S.R. Wolman, K.A. Soper, P.D. Stolley and P. Archer (1986) Chromosome aberrations in individuals occupationally exposed to ethylene oxide, and in a large control population, Mutation Res., 170, 55-74.

Giri, A.K., G. Talukder and A. Sharma (1986) Sister chromatid exchange induced by metanil yellow and nitrite singly and in combination in vivo on mice, Cancer Lett., 31, 299-303.

Giri, A.K., T.S. Banerjee, G. Talukder and A. Sharma (1987) Induction of sister chromatid exchange and dominant lethal mutation by 'Katha' (Catechu) in male mice, Cancer Lett., 36, 189-196.

Hemminki, K., and K. Falck (1979) Correlation of mutagenicity and $4(p$-nitrobenzyl)pyridine alkylation by epoxides, Toxicol. Lett., 4, 103-106.

Hogstedt, B., B. Gullberg, K. Hedner, A.-M. Kolnig, F. Mitelman, S. Skerfving and B. Widegren (1983) Chromosome aberrations and micronuclei in bone marrow cells and peripheral blood leucocytes in humans exposed to ethylene oxide, Hereditas, 98, 105-113.

Hopkins, J. (1984) Genotoxicity and carcinogenicity of glycidyl ether, Food Chem. Toxicol., 22, 780-783.

Kligerman, A.D., G.L. Erexson, M.E. Phelps and J.L. Wilmer (1983) Sister-chromatid exchange induction in peripheral blood lymphocytes of rats exposed to ethylene oxide by inhalation, Mutation Res., 120, 37-44.

Krishna, G., J. Xu, J. Nath. M. Petersen and T. Ong (1985) In vivo cytogenetic studies on mice exposed to ethylene dibromide, Mutation Res., 158, 81-87.

Latt, S.A., J. Allen, S.E. Bloom, A. Carrano, E. Falke, D. Kram, E. Schneider, R. Schreck, R. Tice, B. Whitfield and S. Wolff (1981) Sister chromatid exchanges: a report of the Gene-Tox Program, Mutation Res., 87, 17-62.

Loprieno, N., S. Presciuttini, I. Sbrana, G. Stretti, L. Zaccaro, A. Abbondandolo, S. Bonatti, R. Fiorio and A. Mazzaccaro (1978) Mutagenicity of industrial compounds, VII. Styrene and styrene oxide: II. Point mutations, chromosome aberrations and DNA repair induction analyses, Scand. J. Work Environ. Health, 4, 169-178.

Manson, M. (1980) Epoxides - Is there a human problem?, Br. J. Indust. Med., 37, 317-336.

Margolin, B.H., M.A. Resnick, J.Y. Rimpo, P. Archer, S.M. Galloway, A.D. Bloom and E. Zeiger (1986) Statistical analyses for in vitro cytogenetic assays using Chinese hamster ovary cells, Environ. Mutagen., 8, 183-204.

Maron, D.M., and B.N. Ames (1983) Revised methods for the Salmonella mutagenicity test, Mutation Res., 113, 173-215.

McFee, A.F., K. Lowe and J.R. San Sebastian (1983) Improved sister chromatid differentiation using paraffin-coated bromodeoxyuridine tablets in mice, Mutation Res., 119, $83-88$.
Neau, S.H., B.H. Hooberman, S.W. Frantz and J.E. Sinsheimer (1982) Substituent effects on the mutagenicity of phenyl glycidyl ethers in Salmonella typhimurium, Mutation Res. 93, 297-304.

Nelis, H.J.C.F., S.C. Airy and J.E. Sinsheimer (1982) Comparison of the alkylation of nicotinamide and $4-(p-$ nitrobenzyl)pyridine for the determination of aliphatic epoxides, Anal. Chem., 54, 213-216.

Norppa, H., E. Elovaara, K. Husgafvel-Pursiainen, M. Sorsa and H. Vainio (1979) Effects of styrene oxide on chromosome aberrations, sister chromatid exchange and hepatic drug biotransformation in Chinese hamsters in vivo, Chem.-Biol. Interact., 26, 305-315

Norppa, H., K. Hemminki, M. Sorsa and H. Vainio (1981) Effect of monosubstituted epoxides on chromosome aberrations and SCE in cultured human lymphocytes, Mutation Res., 91, 243-250.

Perry, P., and S. Wolff (1974) New Giemsa method for the differential staining of sister chromatids, Nature (London), 251, 156-158

Preston, R.J., B.J. Dean, S. Galloway, H. Holden, A.F. McFee and $M$. Shelby (1987) Mammalian in vivo cytogenetic assays, Analysis of chromosome aberrations in bone marrow cells, Mutation Res., 189, 157-165.

Rosman, L.B., V.G. Beylin, V. Gaddamidi, B.H. Hooberman and J.E. Sinsheimer (1986) Mutagenicity of para-substituted $\alpha$-methylstyrene oxide derivatives with Salmonella, Mutation Res., 171, 63-70.

Rosman, L.B., V. Gaddamidi and J.E. Sinsheimer (1987) Mutagenicity of aryl propylene and butylene oxides with Salmonella, Mutation Res., 189, 189-204.

Rosman, L.B., P.K. Chakraborty, E.A. Messerly and J.E Sinsheimer (1988) Mutagenicity of aromatic glycidyl ethers with Salmonella, Mutation Res., 206, 115-125.

Salmeen, I., and A.M. Durisin (1981) Some effects of bacteria population on quantitation of Ames Salmonella-histidine reversion mutagenesis assays, Mutation Res., 85, 109-118

Sarto, F., I. Cominato, A.M. Pinton, P.G. Brovedani and C.M Faccioli (1983) Workers exposed to ethylene oxide have increased incidence of sister chromatid exchange, Proc. Int. Sem. on Methods of Monitoring Human Exposure to Carcinogenic and Mutagenic Agents, Espoo, Finland, Dec. 12-15, 1983, IARC, Lyon, France.

Sharief, Y., A.M. Brown, L.C. Backer, J.A. Campbell, B Westbrook-Collins, A.G. Stead and J.W. Allen (1986) Sister chromatid exchange and chromosome aberration analyses in mice after in vivo exposure to acrylonitrile, styrene, or butadiene monoxide, Environ. Mutagen., 8, 439-448.

Sinsheimer, J.E., E. Van den Eeckhout, B.H. Hooberman and V.G. Beylin (1987) Detoxication of aliphatic epoxides by diol formation and glutathione conjugation, Chem.-Biol. Interact., 63, 75-90.

Stolley, P.D., K.A. Soper, S.M. Galloway, W.W. Nichols, S.A Norman and S.R. Wolman (1984) Sister chromatid exchanges in association with occupational exposure to ethylene oxide, Mutation Res., 129, 89-102.

Tice, R.R., J.L. Ivett and A.F. McFee (1987) The effect of agent treatment time on the induction of sister-chromatid 
exchanges in mouse bone marrow cells in vivo, Mutation Res., 182, 15-29.

Wade, D.R., S.C. Airy and J.E. Sinsheimer (1978) Mutagenicity of aliphatic epoxides, Mutation Res., 58, 217-223.

Walk, R.-A., J. Jenderny, G. Rohrborn and U. Hackenberg (1987) Chromosomal abnormalities and sister chromatid exchange in bone marrow cells of mice and Chinese hamsters after inhalation and intraperitoneal administration, I. Diepoxybutane, Mutation Res., 182, 333-342.
World Health Organization (1985) Environmental Health Criteria 46 Guidelines for the Study of Genetic Effects in Human Populations, WHO, Geneva.

Yager, J.W., C.J. Hines and R.C. Spear (1983) Exposure to ethylene oxide at work increases sister chromatid exchanges in human peripheral lymphocytes, Science, 219, 1221-1223. 